\title{
The completeness of the registration system and the economic burden of fatal injuries in Iran
}

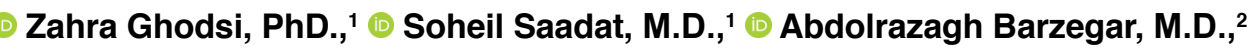 \\ Farshid Alaeddini, M.D.,' (1) Vafa Rahimi-Movaghar, M.D., 1 (1) Mohammadreza Zafarghandi, M.D., ${ }^{1}$ \\ (1) Ardeshir Sheikhazadi, M.D., ${ }^{3}$ (1) Ali Akbari Sari, M.D., ${ }^{4}$ () Payman Salamati, M.D. ${ }^{1}$
}

\begin{abstract}
${ }^{1}$ National Trauma Registry of Iran, Sina Trauma and Surgery Research Center, Tehran University of Medical Sciences, Tehran-Iran ${ }^{2}$ Department of Forensic Medicine, Legal Medicine Research Center, Legal Medicine Organization, Tehran-Iran

${ }^{3}$ Department of Forensic Medicine, Tehran university of Medical Sciences, Faculty of Medicine, Tehran-Iran

${ }^{4}$ Department of Health Management and Economics, School of Public Health, Tehran University of Medical Sciences, Tehran-Iran
\end{abstract}

\begin{abstract}
BACKGROUND: The present study aims to calculate completeness of the current registration system of fatal injuries in the legal Medicine Organization (LMO) and to estimate the economic burden of fatal injuries at the national level of Iran.

METHODS: We estimated the completeness of registered fatal injuries using a three-source capture-recapture method among the Legal Medicine Organization, health departments and Traffic police in Hamedan County (HC) from June 22, 20I5 to June 2I, 2016. We also estimated the economic burden of fatal injuries using Years of Life Lost (YLL) during one year. Then, using appropriate statistical methods, we generalized the estimates to the national level.
\end{abstract}

RESULTS: There were 487 registered fatal injuries in the LMO of HC. The male to female ratio was 2.89. Road Traffic Crashes (RTC) and suicide pertained 45 and 21 percent of deaths, respectively. The completeness of fatal injuries registration was estimated at $86.9 \%$. Based on LMO information of HC, the percentage of fatal injuries numbering errors at the national level was estimated I.I times that was reported by LMO in the same period (4I,936 vs. 36442). YLL and the economic burden of fatal injuries were estimated I,706,373 years and 8,692,264,432 US\$ at the national level, respectively.

CONCLUSION: The completeness of the current registration system of fatal injuries is good. The economic burden of fatal injuries, especially due to motor vehicle crashes in Iran, is substantial. Strategies, legislative actions, and preventive programs should be considered to decrease the number of fatal injuries in our country.

Keywords: Economic burden; Iran; injuries; mortality.

\section{INTRODUCTION}

Although the long-term impact understanding of fatal injuries on societies has stayed as a gap, the profound and specific impact of them from different aspects is not covered on any one. ${ }^{[1,2]}$ The heavy contribution of fatal road traffic crashes, the most common injury-related death, among aged 15-29 or mainly occurrence of suicide and homicide in men aged 15-44 years reveal the importance of socioeconomic burden of years of lost life in particular for lost productivity years. ${ }^{[1,3,4]}$
Premature mortality that arises from fatal injuries imposes substantial economic consequences. ${ }^{[1,5,6]}$ Cost assessment in the US showed that approximately $33 \%$ of the total $\$ 67$ I billion costs of all injuries which had been spent in medical and work-loss were related to fatal injuries. ${ }^{[7]}$ However, it is not only difficult to calculate their exact quantitative costs due to the inability to estimate of intangible costs but also expensive because they are relying on registries and population-based studies. ${ }^{[2,8]}$ Calculating and interpretation of economic burden of fatal injuries in different regions of the world helps

Cite this article as: Ghodsi Z, Saadat S, Barzegar A, Alaeddini F, Rahimi-Movaghar V, Zafarghandi M, et al. The completeness of the registration system and the economic burden of fatal injuries in Iran. Ulus Travma Acil Cerrahi Derg 2020;26:671-677.

Address for correspondence: Payman Salamati, M.D.

Sina Trauma And Surgery Research Center, Sina Hospital, Imam Khomeini Avenue II 367 Tehran, Iran.

Tel: +98 216675700 I E-mail: psalamati@tums.ac.ir

Ulus Travma Acil Cerrahi Derg 2020;26(5):67I-677 DOI: 10.14744/tjtes.2019.34903 Submitted: 07.12.2018 Accepted: II.11.2019 Online: 09.09.2020

Copyright 2020 Turkish Association of Trauma and Emergency Surgery 
policymakers and health planners to alternative strategies, allocate health resources and set priorities, underscoring the needs for the most appropriate interventions and cost-benefit to prevent and control injury-related mortality. ${ }^{[4,9-11]}$ However, the estimating of related costs of fatal injuries depend on the data quality and completeness of injury-related death registries. ${ }^{[12]}$

Low and middle-income countries are worst-affected by fatal injuries where economic inequality occurs at higher levels, and at the same time, the report of deaths information and cause of deaths is categorized as a moderate level. ${ }^{[3,4,12]}$ Due to weak health information sources to capture accurate data, few policies or injury prevention measurements at the national level in use originate in these countries. ${ }^{[2,10]}$ Furthermore, economic burden studies on fatal injuries often are insignificant in these settings, whereas injuries often have significant implications and should be taken into account to better understand the burden. ${ }^{[2]}$

The posed burden of fatal injuries in Iran needs to evaluate the costs based on the more exact number of injury-related mortality to plan prevention and reduction of fatal injuries. It is considered that the magnitude of the economic burden of fatal injuries in a local setting is required for identifying the needs, design specific interventions and raise the scale as a part of approach steps. ${ }^{[2,3]}$ Furthermore, effective interventions should be based on accurate and reliable evidence. The present study aimed to estimate economic burden and the error calculating of registered fatal injuries, after completeness assessing through the capture-recapture method in the country using the Legal Medicine Organization data of Hamadan County for one year.

\section{MATERIALS AND METHODS}

The number of fatal injuries referred to the $L M O$ in $\mathrm{HC}$ was recorded from 22 June 2016 to 21 June 2017 and the age-sex distribution and cause of death of fatalities were extracted. $A$ three capture-recapture method was applied to estimate under-reporting fatal injuries in the LMO resource in $\mathrm{HC}$. The completeness of the registered fatal injuries number in the LMO was obtained by comparing it with the health department and the Traffic Police to detect unregistered deceased in the LMO resource. To realize the best log-linear model, HILOGLINEAR was used in SPSS 21.

To estimate the real number of fatal injuries at the national level based on the percentage of calculating errors in $\mathrm{HC}$, the number and annual incidence of injury-related mortality were calculated during the study period in the County. The national number and rate of fatal injuries were estimated, assuming the same conditions, based on percent errors calculating in Hamedan County, and then it was compared with the LMO report for the same period.
The cost of injury-related mortality in $\mathrm{HC}$ was estimated as follows: the potential years of life lost based on Iranian life expectancy at the age of death reported by the World Health Organization ${ }^{[13]}$ was multiplied by the average annual income per person (based on the World Bank's annual report of "average domestic income per capita for 2016 and 2017" that was $\$ 5,094$ USD). ${ }^{[14]}$ This gives the total lost income for every fatality in HC. Dividing the sum of "the total lost income for every fatality" by the number of fatalities gives the "average income loss per every fatal injury" (AILFI). The AILFI estimated above was multiplied

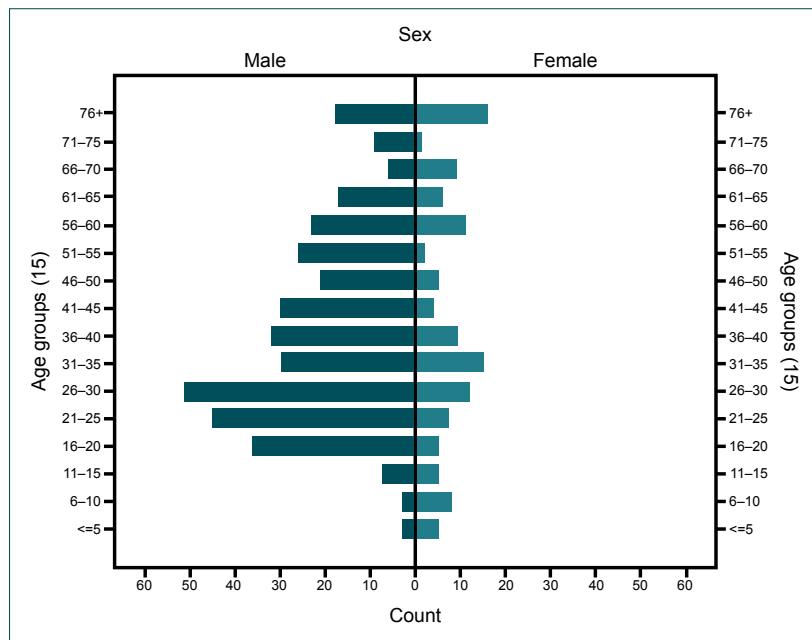

Figure 1. The distribution of 487 fatal injuries by sex and age in Legal Medicine Organization in Hamedan County from 2016 to 2017.

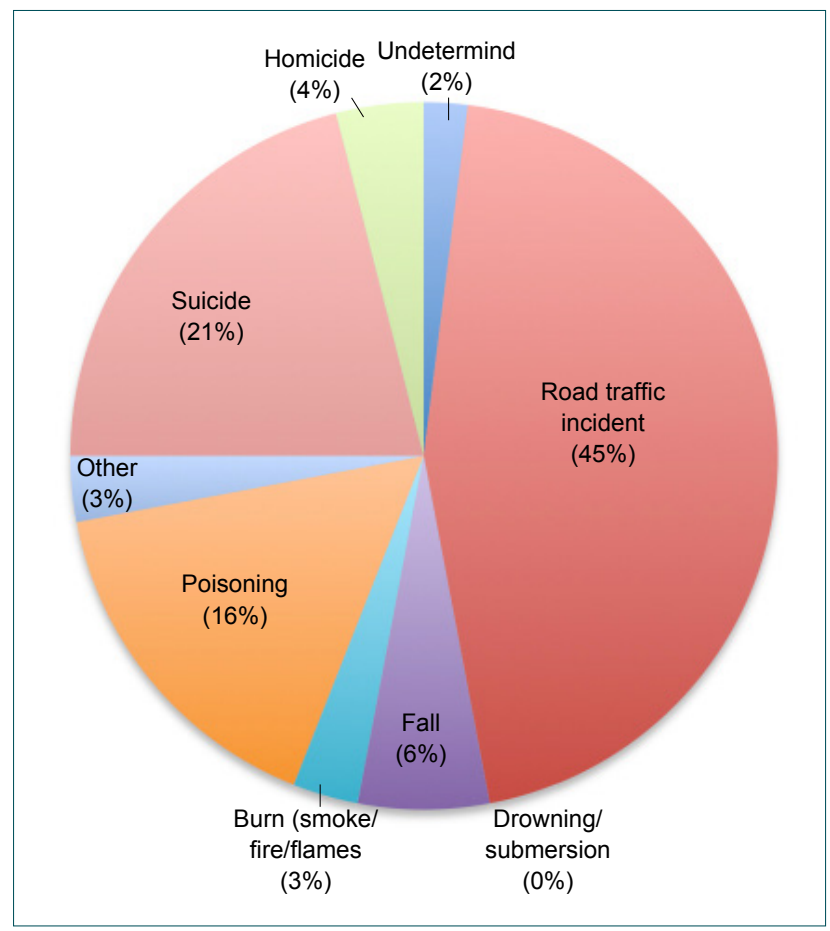

Figure 2. The distribution of 487 fatal injuries by cause of death in Legal Medicine Organization in Hamedan County from 2016 to 2017. 
by "corrected total injury fatality" to estimate the total lost income due to fatal injuries (TLIFI). The research deputy of Tehran University of Medical Sciences (TUMS) Ethical Committee approved the present study. The ethical code was 1395.370.

\section{RESULTS}

Four hundred eighty-seven fatal injuries were recorded in $\mathrm{HC}$ during the study period; at the same time, there were 31 unreported deceased, who was identified by the health de- partment and the Traffic Police resources. Figures of $I$ and 2 show the age-sex and cause of death distribution of recorded fatalities, respectively.

Table I shows the distribution of cause of death by age groups. The most common external cause of death was MVC, The results in different age groups showed that $34.7 \%$ of death arose from MVC occurred in the age group of 26 to 45 years; one-third and one-quarter of fatal falls occurred in the age group of over 65 and 46 to 65 years, respectively. The highest percentage of deaths from burns occurred in the

Table I. The distribution of the 487 fatal injuries by cause of death and age in Legal Medicine Organization in Hamedan County from 2016 to 2017

\begin{tabular}{|c|c|c|c|c|c|c|c|}
\hline \multirow[b]{2}{*}{$\begin{array}{l}\text { Cause of death count } \% \\
\text { within mechanism }\end{array}$} & \multicolumn{6}{|c|}{ Age groups (year) } & \multirow[t]{2}{*}{ Total } \\
\hline & $\leq 5$ & $6-15$ & $16-25$ & $26-45$ & $46-65$ & $>65$ & \\
\hline \multirow[t]{2}{*}{ Motor vehicle crashes } & 10 & 12 & 34 & 77 & 59 & 30 & 222 \\
\hline & $4.5 \%$ & $5.4 \%$ & $14.9 \%$ & $34.7 \%$ & $26.6 \%$ & $13.5 \%$ & $100.0 \%$ \\
\hline \multirow[t]{2}{*}{ Fall of height } & 1 & 2 & 4 & 6 & 8 & 11 & 32 \\
\hline & $3.1 \%$ & $6.3 \%$ & $12.5 \%$ & $18.8 \%$ & $25.0 \%$ & $34.4 \%$ & $100.0 \%$ \\
\hline \multirow[t]{2}{*}{ Cold weapon } & 0 & 0 & 1 & 7 & 0 & 0 & 8 \\
\hline & $0.0 \%$ & $0.0 \%$ & $12.5 \%$ & $87.5 \%$ & $0.0 \%$ & $0.0 \%$ & $100.0 \%$ \\
\hline \multirow[t]{2}{*}{ Drowning } & 2 & I & 2 & 0 & 1 & 0 & 6 \\
\hline & $33.3 \%$ & $16.7 \%$ & $33.3 \%$ & $0.0 \%$ & $16.7 \%$ & $0.0 \%$ & $100.0 \%$ \\
\hline \multirow[t]{2}{*}{ Burn } & 0 & I & 0 & 6 & 3 & 6 & 16 \\
\hline & $0.0 \%$ & $6.25 \%$ & $0.0 \%$ & $37.5 \%$ & $18.7 \%$ & $37.5 \%$ & $100.0 \%$ \\
\hline \multirow[t]{2}{*}{ Drug poisoning } & 0 & I & 12 & 13 & 4 & I & 31 \\
\hline & $0.0 \%$ & $3.2 \%$ & $38.7 \%$ & $41.9 \%$ & $12.9 \%$ & $3.2 \%$ & $100.0 \%$ \\
\hline \multirow[t]{2}{*}{ Poison poisoning } & I & 0 & 9 & 7 & 7 & 2 & 26 \\
\hline & $3.8 \%$ & $0.0 \%$ & $34.6 \%$ & $26.9 \%$ & $26.9 \%$ & $7.7 \%$ & $100.0 \%$ \\
\hline \multirow[t]{2}{*}{ Suffocation } & 0 & 0 & I & 0 & 0 & 1 & 2 \\
\hline & $0.0 \%$ & $0.0 \%$ & $50.0 \%$ & $0.0 \%$ & $0.0 \%$ & $50.0 \%$ & $100.0 \%$ \\
\hline \multirow[t]{2}{*}{ Hanging } & 0 & 3 & 11 & 21 & 13 & 2 & 50 \\
\hline & $0.0 \%$ & $6.0 \%$ & $22.0 \%$ & $42.0 \%$ & $26.0 \%$ & $4.0 \%$ & $100.0 \%$ \\
\hline \multirow[t]{2}{*}{ Electrocution } & 0 & 0 & 1 & 2 & 2 & 0 & 5 \\
\hline & $0.0 \%$ & $0.0 \%$ & $20.0 \%$ & $40.0 \%$ & $20.0 \%$ & $0.0 \%$ & $100.0 \%$ \\
\hline \multirow[t]{2}{*}{ Firearm } & 0 & 0 & 0 & 5 & 1 & 1 & 7 \\
\hline & $0.0 \%$ & $0.0 \%$ & $0.0 \%$ & $71.4 \%$ & $14.3 \%$ & $14.3 \%$ & $100.0 \%$ \\
\hline \multirow[t]{2}{*}{ Hypoxia } & 1 & 3 & 8 & 6 & 2 & 1 & 21 \\
\hline & $4.8 \%$ & $14.3 \%$ & $38.0 \%$ & $28.6 \%$ & $9.5 \%$ & $4.8 \%$ & $100.0 \%$ \\
\hline \multirow[t]{2}{*}{ Drug abuse } & 0 & 0 & 10 & 27 & 10 & 2 & 48 \\
\hline & $0.0 \%$ & $0.0 \%$ & $20.8 \%$ & $56.2 \%$ & $20.8 \%$ & $4.2 \%$ & $100.0 \%$ \\
\hline \multirow[t]{2}{*}{ Hard hit } & 0 & 0 & 0 & 5 & 1 & 2 & 8 \\
\hline & $0.0 \%$ & $0.0 \%$ & $0.0 \%$ & $62.5 \%$ & $12.5 \%$ & $25 \%$ & $100.0 \%$ \\
\hline \multirow[t]{2}{*}{ Other } & 2 & 0 & 0 & 2 & 0 & 0 & 4 \\
\hline & $50.0 \%$ & $0.0 \%$ & $0.0 \%$ & $50.0 \%$ & $0.0 \%$ & $0.0 \%$ & $100.0 \%$ \\
\hline Total & 17 & 23 & 93 & 183 & III & 59 & 487 \\
\hline
\end{tabular}


age group of 26 to 45 years and over 65 years with a similar percentage. The highest percentage of drug abuse and drug poisoning deaths occurred between the ages of 26 and 45 and from other poisonings to the age of 16 to 25 years. The highest and lowest numbers of hanging deaths were seen in the age group of 26 to 45 and years years or less, respectively.

Using log-linear analysis, we estimated 42 fatal injuries that would be hidden from the LMO, the health department and the Police Traffic resources. Thus, the completeness of the LMO was estimated at 86.9 percent.

The total YLL due to fatal injuries in HC was 19,8I6 (Table I). Therefore, the total lost income due to fatal injuries in HC was $\$ 100,942,704$ USD, and the AILFI was $\$ 207,274.5$ USD. According to the LMO, the number of deaths due to injuries was 36,442 for the year $1395^{[15]}$ in the country. The corrected total injury fatality (including those not detected by the LMO) was estimated as $(36,442 / 0.869)=41,936$. Therefore, YLL WAS estimated I,706,373 years and the TLIFI for whole country could be estimated as (41936 × 207274.5) $=\$ 8,692,264,432$ USD (Table 2).

\section{DISCUSSION}

The present study examined the completeness of registered fatal injuries and the estimated economic burden of injury-associated deaths at the national level with the use of the Legal Medicine Organization data source of Hamedan County for one year. It estimated the percentage of calculating errors of fatal injuries at the national level based on the number of cases in the County. Fatal injuries were caused as a massive burden at the national level and mostly by fatal RTC, which is the most cause of death associated with injuries in Iran (19.9 per 100,000). ${ }^{[15]}$

There were about 13 percent of unreported fatal injuries in the LMO of $\mathrm{HC}$. However, the $\mathrm{LMO}$ is the main reliable source to detect the external cause of death. ${ }^{[16]}$ All assumptions of the capture-recapture include closed population; independence, homogeneity, and sufficient information were considered in the study. ${ }^{[17,18]}$ In a study in Ethiopia, the capture of fatal road traffic injuries by the Police and hospital sources was approximately $60 \%$ and $31.5-33.4 \%$, respectively. ${ }^{[19]}$ A study conducted in Iran showed $65 \%$ reported deaths by the LMO source and death registration system (DRS). ${ }^{[17]}$ Incomplete identification of the cause of death, incorrect

Table 2. Frequency distribution and percentage of the lost years of life (YLL) by sex in different age groups in Hamadan County from 22 June 2016 to 21 June 2017

\begin{tabular}{|c|c|c|c|c|c|c|}
\hline \multirow[t]{2}{*}{ Sex/age (year) } & \multicolumn{3}{|c|}{ Male } & \multicolumn{3}{|c|}{ Female } \\
\hline & Frequency & Percent & YLL & Frequency & Percent & YLL \\
\hline$<1$ & 4 & .8 & 298 & 5 & 1.0 & 383 \\
\hline $1-4$ & 2 & .4 & 149.2 & 4 & .8 & 306.4 \\
\hline $5-9$ & 4 & .8 & 282.8 & 8 & 1.6 & 582.4 \\
\hline $10-14$ & 7 & 1.4 & 460.6 & 6 & 1.2 & 407.4 \\
\hline $15-19$ & 26 & 5.3 & I583.4 & 5 & 1.0 & 314.5 \\
\hline $20-24$ & $4 I$ & 8.5 & 2300.1 & 7 & 1.4 & 406.7 \\
\hline $25-29$ & 54 & 11.2 & 2781 & 9 & 1.8 & 478.8 \\
\hline $30-34$ & 36 & 7.5 & 1684.8 & 15 & 3.1 & 724.5 \\
\hline $35-39$ & 32 & 6.7 & 1347.2 & II & 2.3 & 477.4 \\
\hline $40-44$ & 34 & 7.1 & 1268.2 & 5 & 1.0 & 193 \\
\hline $45-49$ & 20 & 4.1 & 652 & 5 & 1.0 & 169 \\
\hline $50-54$ & 19 & 3.9 & 532 & I & .2 & 29 \\
\hline $55-59$ & 27 & 5.5 & 637.2 & II & 2.3 & 268.4 \\
\hline $60-64$ & 17 & 3.5 & 328.1 & 4 & .8 & 79.6 \\
\hline $65-69$ & 12 & 2.5 & 182.4 & II & 2.3 & 173.8 \\
\hline 70-74 & 6 & 1.2 & 68.4 & 2 & .4 & 24 \\
\hline 75-79 & 7 & 1.4 & 58.8 & 4 & .8 & 34.8 \\
\hline $80-84$ & 9 & 1.8 & 55.8 & 8 & 1.6 & 52 \\
\hline $85 \leq$ & 5 & 1.0 & 22.5 & 4 & .8 & 18.8 \\
\hline Total & 362 & 74.6 & 14692.5 & 125 & 25.4 & 5123.5 \\
\hline
\end{tabular}

YLL: Years of the life lost. 
coding and low quality reporting all could be assumed as the main factors. ${ }^{[16]}$ Team related training, exact supervising, and use of the automatic system; all could be mention as effective factors. ${ }^{[20]}$ However, Iran is among medium quality deaths data based on the WHO classification. ${ }^{[12]}$

In the present study within groups of fatal injuries, the distribution of burden was changed strongly in different ages. Of the total YLL due to fatal injuries, $14.5 \%$ of them were among children aged 0-14 years, 82\% among adults (15-64 years), which was accounted as productive years and 3.5\% among the elderly (65 years or more). The economic burden that arose from all fatal injuries was also affected by sex: about three-quarters of the total economic burden of fatal injuries were resulted in men. Thus, the male to female ratio of all injuries was about 2.9:I. Table I shows the most YLL was observed at 20-24 and 30-34 aged groups of men and women, respectively, so the highest economic burden belongs to these groups. In Polinder et al.'s ${ }^{[2]}$ study the highest loss in YLL was observed in men aged between 15-64 years.

In assessing fatal injuries number errors at the national level based on in Hamadan County, it was estimated I.I times that was reported by the LMO in the same period at the national level $\left(41,936\right.$ vs. 36442). ${ }^{[15]}$ Despite the cases are representative for the composition of the Iranian population by age and sex, there is widely affected variation risks of fatal injury in a different region of the country based on a socioeconomic demographic index, culture, geographical location and external cause of deaths at different provinces. ${ }^{[22-26]}$ Failure to correct coding by doctors due to inadequate training, failure to meet the standards for completing the death certificate, and the low quality of the deaths coding all could be considered as the main reasons for the low reporting of the causes of death. ${ }^{[15]}$ However, the access to accurate and valid data helps the best decision to decrease costs resulted in injury-related deaths based on the more exact number of reported fatal injuries of registries. ${ }^{[12]}$ A study showed a 25 percent difference in injury-related mortality statistics between CDC WONDER and GBD 2015 estimates, and percent difference was varied considerably across the cause of death. It is recommended that efforts be made to improve the coding of the cause of death and reduce garbage code to obtain accurate and reliable information on the causes of death. ${ }^{[27]}$

The present study showed that the cost per death in RTC was about 199,924 US\$. Fatal RTC is the main cause of death associated with injuries in Iran (19.9 per 100,000). ${ }^{[15]}$ In Najafi et al.'s ${ }^{[6]}$ study the cost per death that arose from a transport accident was 72,57I US\$. However, the age of the deceased at the time of death could have an effect on YLL. The results emphasize on special attention and control of fatal road traffic crashes, and the development of strategies for effective interventions and management of prevention programs at health sectors and planners.
We know that the cost of premature deaths is not limited to lost income only, but we want to raise that, in a country with 40.6 billion $\$$ in export earnings in 2016 , at least $\$$ 8.7 billion was lost due to fatal injuries. ${ }^{[2]}$ This highlights the need for health policymakers to pay special attention to the significant costs, lost and to allocate resources for preventive interventions, especially in specific areas. An average of 5.5 million barrels of oil per day of fuel is consumed annually in the country, and we can consider using fuel as a source of risk caused by RTC, with a $\$ 4.5$ billion imposed cost due to fatal RTC. ${ }^{[29]}$ As a result, the adoption of risk-based tax measures can be considered solely to improve traffic safety.

The present study had some strength. First, the fatal injury data, as derived from the LMO database where we were represented deceased, died following injury; and delayed injury-related deaths were considered. Second, the economic burden calculations were included in all fatal injuries and it was not restricted to some mechanism or intent. The most important limitation of the current study was that the calculated cost of injuries resulting in death was limited to loss of income. Second, we assumed that the distribution of age-related and sex of fatal injuries in other parts of the country are similar to that of Hamedan, yet there was no reason to exist. Moreover, as a constraint, in the present study, we assumed that under-reporting at the national level is similar to Hamedan. It is based on the assumption that reporting of fatal injuries resulting from an organization where applies the same regulations throughout the country. It is recommended to assess and compare the economic burden of fatal injury on the other province.

Based on the present study, there is under-reporting at fatal injuries registration sources. Also, the lost income of fatal injuries in Iran is substantial and the imposed economic burden is notable. It is important to calculate the real cost of the economic burden of fatal injuries and estimate the percentage of calculating errors. This allows health planners to base their decisions on a more accurate capture and facilitate to identify the best preventive interventions.

\section{Acknowledgment}

The present study is based on the thesis of Zahra Ghodsi to achieve a PhD degree, which was conducted under the supervision of Professor Payman Salamati. We appreciate the personnel of the LMO, especially Mr. Javad Hemati, Health Department, EMS, and Police, who have cooperated in this study.

Ethics Committee Approval: Approved by the local ethics committee.

Peer-review: Internally peer-reviewed.

Authorship Contributions: Concept: P.S.; Design: P.S.; Supervision: P.S.; Fundings: The work was funded and supported by Sina Trauma and Surgery Research Center- Tehran University of Medical Sciences, Thesis code: 93 I 15980 18; Materials: 
P.S., Z.G.; Data: Z.G., P.S., A.B.; Analysis: S.S., F.A., A.A.S.; Literature search: Z.G.; Writing: Z.G., S.S., P.S., V.R.M.; Critical revision: P.S., R.M., A.S., M.Z.

\section{Conflict of Interest: None declared.}

Financial Disclosure: The work was funded and supported by Sina Trauma and Surgery Research Center-Tehran University of Medical Sciences, Thesis code: 931 I5980I8.

\section{REFERENCES}

1. World Health Organization. Injuries and Violence: The Facts 2014. Available from: https://www.who.int/violence_injury_prevention/key_ facts/en/. Geneva, Switzerland: WHO; 2014.

2. Bachani AM, Zhang XJ, Allen KA, Hyder AA. Injuries and violence in the Eastern Mediterranean Region: a review of the health, economic and social burden. East Mediterr Health J 2014;20:64352. [CrossRef]

3. World Health Organization. 10 facts about violence prevention. Available from: http://www.who.int/features/factfiles/violence/en/. Geneva, Switzerland: WHO; 2017.

4. World Health Organization. Road traffic injuries. Available from: http:// www.who.int/news-room/fact-sheets/detail/road-traffic-injuries. Geneva, Switzerland: WHO; 2018.

5. Rezaei S, Arab M, Karami Matin B, Akbari Sari A. Extent, consequences and economic burden of road traffic crashes in Iran. J Inj Violence Res 2014;6:57-63. [CrossRef]

6. Najafi F, Karami-Matin B, Rezaei S, Khosravi A, Soofi M. Productivity costs and years of potential life lost associated with five leading causes of death: Evidence from Iran (2006-2010). Med J Islam Repub Iran 2016;30:412.

7. Florence C, Haegerich T, Simon T, Zhou C, Luo F. Estimated Lifetime Medical and Work-Loss Costs of Emergency Department-Treated Nonfatal Injuries--United States, 2013. MMWR Morb Mortal Wkly Rep 2015;64:1078-82. [CrossRef]

8. Yang L, Lam LT, Liu Y, Geng WK, Liu DC. Epidemiological profile of mortality due to injuries in three cities in the Guangxi Province, China. Accid Anal Prev 2005;37:137-41. [CrossRef]

9. Saadat S, Yousefifard M, Asady H, Moghadas Jafari A, Fayaz M, Hosseini M. The Most Important Causes of Death in Iranian Population; a Retrospective Cohort Study. Emerg (Tehran) 2015;3:16-21.

10. World Health Organization. National injury prevention policies, strategies and plans of action. Available from: http://www.who.int/violence_injury_prevention/policy/introduction/en/. Geneva, Switzerland: WHO; 2018.

11. Khosravi A, Taylor R, Naghavi M, Lopez AD. Mortality in the Islamic Republic of Iran, 1964-2004. Bull World Health Organ 2007;85:607-4.

12. World Health Organization. World Health Statistics 2017: Monitoring health for the SDGs, Sustainable Development Goals. Available from: https://www.who.int/gho/publications/world_health_statistics/2017/ en/. Geneva, Switzerland: WHO; 2017.

13. World Health Organization. Life tables by country Iran (Islamic Republic of). 2015. Available from: https://apps.who.int/gho/data/view. main.60760.
14. The World Bank. Iran Overview 2018. Available from: https://www. worldbank.org/en/country/iran/overview.

15. Iranian Legal Medicine Organization. Statistical Yearbook of the Forensic Medicine Organization 2016 [cited 2016 May 10]. Available from: http://www.lmo.ir.

16. Khosravi A, Aghamohammadi S, Kazemi E. Guidance for recording and classifying causes of death. 1st edition. Tehran: Ministry of Health, Treatment and Medical Education, Deputy Minister of Health, Network Management, 2016.

17. Zavareh DK, Mohammadi R, Laflamme L, Naghavi M, Zarei A, Haglund BJA. Estimating road traffic mortality more accurately: use of the capture-recapture method in the West Azarbaijan Province of Iran. Int J Inj Control Sa 2008;15:9-17. [CrossRef]

18. Bierrenbach A. Capture Recapture. Available from: https://www.who. int/tb/advisory_bodies/impact_measurement_taskforce/meetings/ ie_oct09_capture_recapture.pdf. Accessed May 27, 2020.

19. Abegaz T, Berhane Y, Worku A, Assrat A, Assefa A. Road traffic deaths and injuries are under-reported in Ethiopia: a capture-recapture method. PLoS One 2014;9:e103001. [CrossRef]

20. World Health Organization. Improving Mortality Statistics through Civil Registration and Vital Statistics Systems, Strategies for country and partner support. Available from: https://www.who.int/healthinfo/civil_registration/CRVS_MortalityStats_Guidance_Nov2014.pdf?ua=1. Geneva, Switzerland: WHO; 2014.

21. Polinder S, Haagsma JA, Toet H, van Beeck EF. Epidemiological burden of minor, major and fatal trauma in a national injury pyramid. Br J Surg 2012;99:114-21. [CrossRef]

22. Azizpour Y, Asadollahi K, Sayehmiri K, Kaikhavani S, Abangah G. Epidemiological survey of intentional poisoning suicide during 1993-2013 in Ilam Province, Iran. BMC Public Health 2016;16:902. [CrossRef]

23. Najafi F, Beiki O, Ahmadijouybari T, Amini S, Moradinazar M, Hatemi $\mathrm{M}$, et al. An assessment of suicide attempts by self-poisoning in the west of Iran. J Forensic Leg Med 2014;27:1-5. [CrossRef]

24. Kristiansen T, Lossius HM, Rehn M, Kristensen P, Gravseth HM, Røislien J, et al. Epidemiology of trauma: a population-based study of geographical risk factors for injury deaths in the working-age population of Norway. Injury 2014;45:23-30. [CrossRef]

25. De Leo D, Milner A, Fleischmann A, Bertolote J, Collings S, Amadeo S, et al. The WHO START study: suicidal behaviors across different areas of the world. Crisis 2013;34:156-63. [CrossRef]

26. Jamshidi F, Fathi G, Davoodzadeh H. Investigation Paraquat Poisoning in Southwest of Iran - from Sign to Mortality and Morbidity. Arch Med Sadowej Kryminol 2017;67:35-45. [CrossRef]

27. Wu Y, Cheng X, Ning P, Cheng P, Schwebel DC, Hu G. Comparing U.S. Injury Death Estimates from GBD 2015 and CDC WONDER. Int J Environ Res Public Health 2018;15:87. [CrossRef]

28. Iran (IRN) Exports, Imports and Trade Partners. Available from: https://atlas.media.mit.edu/en/profile/country/irn/. Accessed May 27, 2020.

29. The Iran Project. Oil Minister: Fuel consumption volume in Iran equivalent to 5.5m BPD. 2018. Available from: https://theiranproject.com/ blog/2018/02/06/oil-minister-fuel-consumption-volume-iran-equivalent $-5-5 \mathrm{~m}-\mathrm{bpd} /$. 


\section{ORİJINAL ÇALIŞMA - ÖZET}

\section{İran'da kayıt sisteminin bütünlüğü ve ölümcül yaralanmaların ekonomik yükü}

Dr. Zahra Ghodsi, ${ }^{1}$ Dr. Soheil Saadat, ${ }^{1}$ Dr. Abdolrazagh Barzegar, ${ }^{2}$ Dr. Farshid Alaeddini, ${ }^{1}$

Dr. Vafa Rahimi-Movaghar, ${ }^{1}$ Dr. Mohammadreza Zafarghandi, ${ }^{1}$ Dr. Ardeshir Sheikhazadi, ${ }^{3}$

\section{Dr. Ali Akbari Sari, ${ }^{4}$ Dr. Payman Salamati ${ }^{1}$}

${ }^{1}$ İran Ulusal Travma Sicili, Sina Travma ve Cerrahi Araştırma Merkezi, Tahran Tıp Bilimleri Üniversitesi, Tahran-Iran

${ }^{2}$ Yasal Tıp Araştırma Merkezi, Adli Tıp Örgütü, Adli Tıp Bölümü, Tahran-Iran

${ }^{3}$ Tahran Tıp Bilimleri Üniversitesi Tıp Fakültesi, Adli Tıp Anabilim Dalı, Tahran-Iran

${ }^{4}$ Tahran Tıp Bilimleri Üniversitesi Halk Sağlığı Fakültesi, Sağlık Yönetimi ve Ekonomi Bölümü, Tahran-Iran

AMAÇ: Bu çalışmanın amacı, Yasal Tıp Teşkilatı (LMO) içerisinde ölümcül yaralanmaların mevcut kayıt sisteminin bütünlüğünü hesaplamak ve İran'da ulusal düzeyindeki ölümcül yaralanmaların ekonomik yükünü tahmin etmektir.

GEREÇ VE YÖNTEM: 22 Haziran 2015-2I Haziran 2016 tarihleri arasında Hamedan Bölgesi'nde (HC) Yasal Tıp Teşkilatı, sağlık departmanları ve trafik polisi arasında üç kaynaklı yakalama-yeniden yakalama yöntemi kullanılarak kaydedilen ölümcül yaralanmaların bütünlüğünü değerlendirildi. Ayrıca, bir yıl boyunca Kaybedilmiş Yıllar (KY) ölçütü kullanarak ölümcül yaralanmaların ekonomik yükü de değerlendirildi. Ardından, uygun istatistiksel yöntemleri kullanarak tahminleri ulusal düzeyde genelleştirdik.

BULGULAR: Hamedan Bölgesi LMO'sunda 487 kayıtlı ölümcül yaralanma vardı. Erkek/kadın oranı 2.89 idi. Karayolu Trafik Kazaları (RTC) ve intihar, ölümlerin sırasıyla yüzde 45 ve yüzde 2 l'ini oluşturmaktaydı. Ölümcül yaralanma kayıt bütünlüğünün \%86.9 olduğu tahmin edilmektedir. Hamedan Bölgesi'nin LMO bilgilerine dayanarak, ulusal düzeydeki ölümcül yaralanma numaralandırma hatalarının yüzdesinin, aynı dönemde LMO tarafından bildirilenin I.I katı olduğu tahmin edilmektedir (4I.936'e karşı 36442). Kaybedilmiş yıllar ve ölümcül yaralanmaların ekonomik yükünün ulusal düzeyde sırasıyla I.706.373 yıl ve 8.692.264.432 ABD doları olduğu tahmin edilmektedir.

TARTIŞMA: Ölümcül yaralanmalara ait mevcut kayıt sisteminin bütünlüğü iyidir. İran'da özellikle motorlu taşıt kazaları nedeniyle ölümcül yaralanmaların ekonomik yükü büyüktür. Ülkemizdeki ölümcül yaralanma sayısını azaltmak için stratejiler, yasal eylemler ve önleyici programlar göz önünde bulundurulmalıdir.

Anahtar sözcükler: Ekonomik yük; İran; mortalite; yaralanmalar.

Ulus Travma Acil Cerrahi Derg 2020;26(5):67I-677 doi: 10.14744/tjtes.2019.34903 